BNWL-1845-11

UC-23

Special Distribution

\title{
Pacific Northwest Laboratory Monthly Report \\ to Space Nuclear Systems \\ Division \\ for May 1975
}

by

H. T. Fullam

June 1975

Prepared for the U.S. Energy

Research and Development Administration under Contract AT(45-1):1830 
NOTICE

This report was prepared as an account of work sponsored by the United States Government. Neither the United States nor the United States Energy Research and Development Administration, nor any of their employees, nor any of their contractors, subcontractors, or their employees, makes any warranty, express or implied, or assumes any legal liability or responsibility for the accuracy, completeness or usefulness of any information, apparatus, product or process disclosed, or represents that its use would not infringe privately owned rights.

PACIFIC NORTHWEST LABORATORY

operated by

BATTELLE

for the

U.S. ENERGY RESEARCH AND DEVELOPMENT ADMINISTRATION

Under Contract AT(45-1)-1830

Printed in the United States of America

Available from

National Technical Information Service

U.S. Department of Commerce

5285 Port Royal Road

Springfield, Virginia 22151

Price: Printed Copy \$4.00; Microfiche $\$ 2.25$

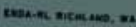


PACIFIC NORTHWEST LABORATORY MONTHLY REPORT

TO SPACE NUCLEAR SYSTEMS DIVISION FOR MAY 1975

By

H. T. Fullam

June 1975

Battelle

Pacific Northwest Laboratories

Richland, Washington 99352 
STRONTIUM HEAT SOURCE DEVELOPMENT PROGRAM . . . . . . . 1 DISSOLUTION RATE STUDIES .............. 1 LONG-TERM COMPATIBILITY STUDIES . . . . . . . . . 1 THERMODYNAMIC ANALYSIS ............. 2 TECHNOLOGY REVIEW MEETING ............ 2 


\author{
PACIFIC NORTHWEST LABORATORY \\ MONTHLY REPORT \\ TO SPACE NUCLEAR SYSTEMS DIVISION \\ FOR MAY 1975
}

\title{
STRONTIUM HEAT SOURCE DEVELOPMENT PROGRAM
}

At Hanford, strontizm will be separated from the high-level waste, then converted to the fluoride, and doubly encapsulated in small, high-integrity containers for subsequent long-term storage. The fluoride conversion, encopsulation and storage will take place in the Waste Encapsulation and Storage Facilities (WESF). This encapsulated strontium fluoride represents an economical source of ${ }^{90}$ Sr if the WESF capsule can be licensed for heat source applications under anticipated use conditions. The objectives of this program are to obtain the data needed to license ${ }^{90}{ }_{S r F}$ heat sources and specifically the WESF ${ }^{90}{ }_{S r F} 2$ capsules. The information needed for licensing can be divided into three general areas:

1. Long-term $\mathrm{SrF}_{2}$ compatibility data.

2. Chemical and physical property data on ${ }^{90} \mathrm{SrF} 2$.

3. Capsule property data such as external corrosion resistance, crush strength, etc.

The current program is designed to provide the required information.

\section{DISSOLUTION RATE STUDIES}

The study to determine the effect of temperature on the dissolution rate of nonradioactive $\mathrm{SrF}_{2}$ in seawater was stopped due to failure of the metering pump. The pump has been returned to the manufacturer for repair. As soon as the repairs are effected; the dissolution studies will be resumed.

\section{LONG-TERM COMPATIBILITY TESTS}

All the hardware required for the long-term compatibility tests have been fabricated except for a sma11 number of Charpy impact test specimens which will be fabricated in July. 
Current planning calls for three materials to be evaluated in the long-term compatibility tests: Haynes 25, Hastelloy C-276, and TZM. Because of problems involving the long-term aging of Haynes 25 and Hastelloy $\mathrm{C}-276$, it has been decided to evaluate Hastelloy $\mathrm{C}-4$ as a potential containment material. Initial tests will be designed to evaluate the effect of long-term aging on the high temperature properties of the alloy. Charpy impact test specimens will be held at temperatures of 600 to $1000^{\circ} \mathrm{C}$ for long time periods and then tested to determine the effect of aging on the toughness of the alloy. If the results are promising, the compatibility tests will be modified to include the Hastelloy C-4.

\section{THERMODYNAMIC ANALYSIS}

The preliminary thermodynamic analysis of $\mathrm{WESF}^{90} \mathrm{SrF}_{2}$-alloy systems was completed and the results presented in earlier reports. A more detailed thermodynamic analysis of the three systems to be tested in the long-term compatibility tests is now under way. The three systems under consideration are:

1. WESF ${ }^{90} \mathrm{SrF}_{2}$ - Haynes 25

2. WESF ${ }^{90} \mathrm{SrF}_{2}$ - Hastelloy $\mathrm{C}-276$

3. WESF ${ }^{90} \mathrm{SrF}_{2}-\mathrm{TZM}$

The study is being carried out by Dr. Carl Alexander and his associates at Battelle's Columbus Laboratories.

\section{TECHNOLOGY REVIEW MEETING}

K. M. Harmon, H. H. Van Tuy 1, J. H. Jarrett, and H. T. Fullam attended a technology review meeting on May 14-15 at Germantown, Maryland sponsored by the Isotope Technology Branch of SNS. J. H. Jarrett presented a paper on the Strontium Heat Source Development Program at the meeting. 
BNWL-1845-11

UC -23

Special Distribution

\section{DISTRIBUTION}

No. of

Copies

OFFSITE

1

2

2

1

\section{ERDA Chicago Patent Attorney 9800 S. Cass Avenue \\ Argonne, IL 60439}

A. A. Churm

ERDA Division of Biomedical and Environmental Research Washington, $D C$

J. N. Maddox

L. A. Miller

ERDA Division of Production and Materials Management Washington, DC 20545

F. P. Baranowski

ERDA Division of Space Nuclear Systems Washington, DC 20545

R. T. Carpenter

G. P. Dix

T. J. Dobry, Jr.

D. S. Gabrie1

N. Goldenberg

H. Jaffe

W. K. Kern

A. P. Litman

G. A. Newby

D. J. Rock

ERDA Division of Waste Management and Transportation Washington, DC 20545

F. K. Pittman

R. W. Ramsey, Jr.

ERDA Oak Ridge Operations Office

P.0. Box E

Oak Ridge, TN 37830

D. C. Davis, Jr. 
No. of

Copies

3

ERDA Savannah River Operations office

P.0. Box A

Aiken, SC 29801

R. H. Bass

T. B. Hindman

R. K. Huntoon

\section{ERDA Technical Information Center}

Department of the Army Headquarters, U.S. Army Facilities Engineering Support Agency

Fort Belvoir, Virginia 22060

FESA-RTD

Electronics and Applied Physics Division

Building 347.3, AERE Harwe11

Oxfordshire OX11 ORA

Great Britain

E. H. Cooke-Yarborough

1 General Atomic Company (San Diego)

P.0. Box 81601

San Diego, CA 92138

H. C. Carney

1 General Electric Company MSVD

P.0. Box 8555

Philadelphia, PA 19101

P. E. Brown

General Electric Company, Vallecitos Laboratory

P.0. Box 846

Pleasanton, CA 94566

G. E. Robinson

2

Los Alamos Scientific Laboratory

P.0. Box 1663

Los Alamos, NM 87544

T. K. Keenan

R. N. Mulford 
No. of

Copies

$1 \quad$ Monsanto Research Corporation

Mound Laboratory (ERDA)

Nuclear Operations

P.0. Box 32

Miamisburg, $\mathrm{OH} 45342$

W. T. Cave

$1 \quad$ Naval Nuclear Power Division

Ft. Belvoir, VA 22060

F. E. Roselle

3 Naval Facilities Engineering Command

Nuclear Power Division (FAC042)

Washington, DC 20390

T. P. Fleming

G. E. Krauter

M. Starr

Navy Office of the Chief of Naval Operations

Washington, DC 20350

Head, Reactor Branch

$7 \quad$ Holifield National Laboratory

Oak Ridge, TN 37830

R. S. Crouse

J. R. DiStefano

J. H. Gillette

E. Lamb

C. Ottinger

J. E. Ratledge

A. F. Rupp

$1 \quad$ Teledyne Isotopes

110 W. Timonium Road

Timonium, MD 21093

P. Vogelberger

1 Westinghouse Astronuclear Laboratory

P.0. Box 10864

Pittsburgh, PA 15236

C. C. Silverstein 
No. of

Copies

ONSITE

1

ERDA Richland Operations office

B. J. Melton

8

Atlantic Richfield Hanford Company

L. I. Brecke

R. E. Isaacson

L. M. Knights

C. W. Malody

J. D. Moore

G. C. Oberg

H. P. Shaw

M. J. Szul inski

2

D. W. Douglas Laboratories

D. W. Knapp

W. E. Matheson

23 Battelle-Northwest

J. W. Bartlett

R. E. Burns

T. D. Chikalla

R. L. Dillon

J. W. Finnigan

H. T. Fullam (3)

A. J. Haverfield

J. H. Jarrett

R. S. Kemper

R. P. Marshall

R. W. McKee

J. M. Nielsen

R. E. Nightingale

L. D. Perrigo

A. M. Platt

J. L. Simmons

H. H. Van Tuyl

Technical Information Files (3)

Technical Publications 